\title{
Availability of heavy metals in contaminated soil evidenced by chemical extractants
}

\author{
Maria Ligia de Souza Silva1, Camila de Carvalho Braga Levy², Godofredo Cesar Vitti ${ }^{3}$
}

\begin{abstract}
Heavy metals have been accumulating in Brazilian soils, due to natural processes, such as atmospheric deposition, or human industrial activities. For certain heavy metals, when in high concentrations in the soil, there is no specific extractant to determine the availability of these elements in the soil. The objective of the present study was to evaluate the availability of $\mathrm{Cd}, \mathrm{Cu}, \mathrm{Fe}, \mathrm{Mn}, \mathrm{Pb}$ and $\mathrm{Zn}$ for rice and soybeans, using different chemical extractants. In this study we used seven soil samples with different levels of contamination, in completely randomized experimental design with four replications. We determined the available concentrations of $\mathrm{Cd}, \mathrm{Cu}, \mathrm{Fe}, \mathrm{Mn}, \mathrm{Pb}$ and $\mathrm{Zn}$ extracted by Mehlich-1, $\mathrm{HCl} 0.1$ mol L-1, DTPA, and organic acid extractants and the contents in rice and soybeans, which extracts were analyzed by ICP-OES. It was observed that Mehlich-1, $\mathrm{HCl} 0.1 \mathrm{~mol} \mathrm{~L}^{-1}$ and DTPA extractants were effective to assess the availability of $\mathrm{Cd}, \mathrm{Cu}, \mathrm{Pb}$ and $\mathrm{Zn}$ for rice and soybeans. However, the same was not observed for the organic acid extractant.
\end{abstract}

Key words: plant uptake, cadmium, lead, soil pollution.

\section{RESUMO}

\section{Disponibilidade de metais pesados a estratores químicos em solos contaminados}

Metais pesados vêm se acumulando em solos brasileiros em razão de processos naturais, como deposições atmosféricas, ou atividades antropogênicas. Para alguns metais pesados, em condição de altas concentrações no solo, não existe um extrator especifico que avalie sua biodisponibilidade. Objetivou-se no presente trabalho, avaliar a biodisponibilidade dos elementos $\mathrm{Cd}$, $\mathrm{Cu}, \mathrm{Fe}, \mathrm{Mn}, \mathrm{Pb}$ e Zn para plantas de arroz e soja, utilizando diferentes extratores químicos. Neste estudo foram utilizadas sete amostras de solos com diferentes graus de contaminação, em delineamento experimental inteiramente casualizado, com quatro repetições. Foram determinados os teores disponíveis de Cd, Cu, Fe, Mn, Pb e Zn extraídos pelas soluções de Mehlich-1, HCl 0,1 mol L-1, DTPA e ácidos orgânicos, e os teores desses elementos em plantas de arroz e soja, cujos extratos foram analisado por ICP-OES. Observou-se que os extratores Mehlich-1, HCl 0,1 mol L-1 e DTPA foram eficientes para avaliar a disponibilidade de $\mathrm{Cd}, \mathrm{Cu}, \mathrm{Pb}$ e Zn para plantas de arroz e soja. O mesmo não foi observado para os extratores derivados de ácidos orgânicos.

Palavras-chave: absorção por plantas, cádmio, chumbo, poluição de solo.

\footnotetext{
Recebido para publicação em 17/01/2012 e aprovado em 01/06/2012

${ }^{1}$ Agronomist Engineer. Departamento de Agronomia, Universidade Estadual do Centro-Oeste (UNICENTRO), Rua Simeão Camargo Varela de Sá, 3, Vila Carli, 85040-080, Guarapuava, Paraná, Brazil. mlsousi@hotmail.com (corresponding author)

${ }^{2}$ Agronomist Engineer. Master Science student of Instituto Agronômico de Campinas (IAC), Avenida Barão de Itapura, 1481, 13020-902, Campinas, São Paulo, Brazil. ciriemaesalq@hotmail.com

${ }^{3}$ Agronomist Engineer. Departamento de Ciência do Solo, Escola Superior de Agricultura “Luiz de Queiroz” (ESALQ/USP), Avenida Pádua Dias, 11, Caixa Postal 09, 13418-900, Piracicaba, São Paulo, Brazil. gcvitti@esalq.usp.br
} 


\section{INTRODUCTION}

Heavy metals may be accumulating in Brazilian soils due to natural processes such as atmospheric deposition, or due to human interference, such as with industrial activities, disposal of sewage sludge, disposal of waste or domestic and industrial by-products, as well as with the use of fertilizers and pesticides (Amaral Sobrinho et al., 2009).

The success of monitoring heavy metals in the soil depends partly on an efficient chemical method that can measure the fraction of these elements available to plants. Heavy metal availability can be assessed using a suitable extractant, in which the amount extracted is associated with the accumulation or with the concentration of the elements in plants. Among the most used extractants in the assessment of the availability of elements in the soil, there are the DTPA and the Mehlich 1 (Raij, 1994). According to Abreu et al. (2002) the acidic solutions that were most tested for the extraction of available forms of heavy metals in plants are $\mathrm{HCl} 0.1 \mathrm{~mol} \mathrm{~L}^{-1}$ and Mehlich-1.

The DTPA extracting solution at $\mathrm{pH}$ 7.3, as proposed by Lindsay and Norvell (1978), was initially developed to assess the bioavailability of copper (Cu), iron (Fe), manganese $(\mathrm{Mn})$ and zinc $(\mathrm{Zn})$ in soils with $\mathrm{pH}$ near neutrality or above, and Mehlich-1, to check the availability of $\mathrm{P}$ and exchangeable cations. These methods, however, had their usability expanded and have now been used in the extraction of lead (Pb), cadmium (Cd) and nickel (Ni) (Mattiazzo et al., 2001).

In Brazil, results found for different extractants of heavy metals in soil are quite contradictory, especially those concerning the availability of $\mathrm{Cd}, \mathrm{Pb}$, chromium (Cr) and $\mathrm{Ni}$, which are elements often found in steel industry and organic waste (Abreu et al., 1995; Abreu et al., 1998; Mattiazzo et al., 2001; Pires et al., 2004).

One of the major criticisms made to chemical extractants is that they do not simulate the reactions that occur near the roots, especially those at the rhizosphere. Mench \& Martin (1991) found that the exudates of roots collected from three plant species (Nicotiana tabacum L., Nicotiana rústica L. and Zea mays L.) have increased the solubility of $\mathrm{Mn}$ and $\mathrm{Cu}$. They also found that $\mathrm{Cd}$ amounts extracted by the exudates were proportional to the amounts of the element accumulated by these three plant species when cultured in the soil. Krishnamurti et al. (1997) when evaluating the kinetics of Cd release in soil, stressed the importance of low molecular weight organic acids excreted by the roots to the understanding of element availability. Low molecular weight organic acids, such as acetic, citric, oxalic, fumaric and succinic, usually found in root exudates, are the most effective in solubilizing heavy metals in the soil.
The acetic, citric, lactic and oxalic acids were the main organic acids found in the rhizosphere of the different plants studied. In studies using a solution consisting of organic acids (acetic acid, $1.0 \mathrm{~mol} \mathrm{~L}^{-1}$, citric acid, $0.72 \mathrm{~mol} \mathrm{~L}^{-1}$, lactic acid, $0.49 \mathrm{~mol} \mathrm{~L}^{-1}$ and oxalic acid $0.12 \mathrm{~mol} \mathrm{~L}^{-1}$ ), to assess the availability of $\mathrm{Cd}, \mathrm{Cu}, \mathrm{Ni}, \mathrm{Pb}$ and $\mathrm{Zn}$ in soils treated with sewage sludge, researchers have found that the extractor solution was effective in assessing the availability of heavy metals, especially Pb (Pires et al., 2004).

This work aimed to evaluate the available concentrations of heavy metals in contaminated soils at the end of rice and soybean cultivation, using different extractants.

\section{MATERIAL AND METHODS}

The study was conducted in a greenhouse using soil from the surface layer $(0-20 \mathrm{~cm})$ of a clayey Oxisol, according to the classification of Embrapa (1999), which had different levels of contamination associated with environmental accidents. Soil sampling was conducted in an area near a factory in the city of Paulinia-SP.

Since contamination was associated with the wind, the soil was collected following the predominant direction of the wind, at equidistant points $100 \mathrm{~m}$, starting from the pollution source, and organized and named as follows: Point 1 - P1 (100 m) Point 2 - P2 (200 m) Point 3 - P3 (300 m) Point 4 - P4 (400 m) Point 5 - P5 (500 m) Point 6 - P6 (600 m) Point 7 - P7 (700 m). In order to determine the level of contamination in every sampled point location, samples of approximately $1 \mathrm{~kg}$ were taken from soil, oven-dried, sieved in a $2 \mathrm{~mm}$ sieve and analyzed for $\mathrm{pH}\left(\mathrm{CaCl}_{2}\right)$, organic matter (OM), phosphorus (P), potassium (K), calcium (Ca), magnesium $(\mathrm{Mg})$ and active acidity $(\mathrm{H}+\mathrm{Al})$ (Raij et al., 2001). The total contents of $\mathrm{Cd}, \mathrm{Cu}, \mathrm{Fe}, \mathrm{Mn}, \mathrm{Pb}$ and $\mathrm{Zn}$ were determined employing aqua regia (3:1 mixture of $\mathrm{HCl} /$ $\mathrm{HNO}_{3}$ ) according to the methodology described in Nieuwenhuize et al. (1991) (Table 1).

The available concentration of $\mathrm{Cd}, \mathrm{Cu}, \mathrm{Fe}, \mathrm{Mn}, \mathrm{Pb}$ and $\mathrm{Zn}$ in the samples were extracted using four extractants: a)

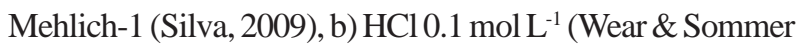
, 1947), c) DTPA(Lindsay \& Norvell, 1978) and d) solution of organic acids (acetic $1 \mathrm{~mol}^{-1} \mathrm{~L}$, citric $0.72 \mathrm{~mol} \mathrm{~L}^{-1}$; lactic $0.49 \mathrm{~mol} \mathrm{~L}^{-1}$; oxalic $0.12 \mathrm{~mol} \mathrm{~L}^{-1}$ ) whose concentrations were determined by Pires et al. (2004).

The experiment followed a completely randomized design with four replications, in pots of $5 \mathrm{dm}^{3}$. The species used in the experiment were Oriza sativa L. cultivar IAC 202 and Glycine max L. cultivar BRS 133. The NPK fertilization was performed according to the needs of the crop, following the recommendations of Raij et al. (1997).

Ten seeds were sown per pot and after 15 days of germination thinning was carried out, leaving only four plants per pot. The watering of the pots occurred so as not to exceed a maximum of $70 \%$ and minimum of $40 \%$ of 
holding capacity of water of the soil, with daily weighting of pots.

Leaves for diagnosis of nutritional status were collected following the procedure described by Malavolta et al. (1997). The samples were washed in tap water and then rinsed in distilled water, placed in paper bags and submitted to a drying process using forced aeration, with temperature maintained from 60 to $70^{\circ} \mathrm{C}$ until constant weight. After drying, they were ground in a Willey type mill and packed in plastic bags. The wet digestion of plant samples was performed in open system, using adaptation of the method described by Oliva et al. (2003). The concentrations of $\mathrm{Cd}, \mathrm{Cu}, \mathrm{Fe}, \mathrm{Mn}, \mathrm{Pb}$ and $\mathrm{Zn}$ in extracts of plant and soil were determined by inductively coupled plasma atomic emission spectroscopy (ICP-OES) (Miyazawa et al., 2009).

The available concentrations of heavy metals in soil were subjected to analysis of variance and $\mathrm{F}$ test. Linear correlation analyses were also performed among the available concentrations of the elements in the soil, and the amounts accumulated by rice and soybeans. The correlation coefficient values ( $\mathrm{r}$ ) were compared to evaluate the effectiveness of the extractants. Statistical analyses were performed according to Pimentel Gomes \& Garcia, 2002 using $5 \%$ as the significance level $(\mathrm{p}<0,05)$.

\section{RESULTS AND DISCUSSION}

The chemical analysis of soil samples used in this study showed that they had no limitations on fertility (Table 1), showing weak acidity, proper levels of macronutrients and base saturation above 50\%, except for P7 (farther point from the pollution source). However, the limitations of this soil can be attributed to the high concentrations of heavy metals found, because they interfered with the development of rice plants, causing plant death at the beginning of the development in P1, thus demonstrating that rice may be sensitive to high concentrations of heavy metals in the soil.

The soils used in this study had high total concentrations of Cd (20 - $\left.27 \mathrm{mg} \mathrm{kg}^{-1}\right)$, Cu (120 - $272 \mathrm{mg}$ $\mathrm{kg}^{-1}$ ), Fe (97 - $\left.936 \mathrm{mg} \mathrm{kg}^{-1}\right)$; Mn (535- $\left.719 \mathrm{mg} \mathrm{kg}^{-1}\right), \mathrm{Pb}$ (173 - $\left.332 \mathrm{mg} \mathrm{kg}^{-1}\right)$ and $\mathrm{Zn}\left(101-553 \mathrm{mg} \mathrm{kg}^{-1}\right)$. For the state of São Paulo, CETESB, in 2005, published the guiding values of concentrations of heavy metals in soil for prevention, contamination control and management of contaminated sites under investigation. According to these, the concentrations of $\mathrm{Cd}$, determined for this soil, are in all sampled points, above the levels of intervention for the agricultural area ( $3 \mathrm{mg} \mathrm{kg}^{-1}$ ). The same is true for $\mathrm{Pb}$, because all points had levels above the level of intervention for the agricultural area (180 $\left.\mathrm{mg} \mathrm{kg}^{-1}\right)$, except P3. However, the levels of P3 are above those set by CETESB as preventive level (72 $\left.\mathrm{mg} \mathrm{kg}^{-1}\right)$. The value of prevention is the concentration of a particular substance, above which adverse changes may occur to the quality of soil and groundwater (CETESB, 2005).

The elements $\mathrm{Cu}$ and $\mathrm{Zn}$, only in $\mathrm{P} 1$, showed levels above $200 \mathrm{mg} \mathrm{kg}^{-1}$ for $\mathrm{Cu}$ and $450 \mathrm{mg} \mathrm{kg}^{-1}$ for $\mathrm{Zn}$, these values are established as values of intervention for agricultural area, according to CETESB (2005). Since Fe and $\mathrm{Mn}$ concentrations do not have reference value established by CETESB.

Table 2 shows the concentrations of $\mathrm{Cd}, \mathrm{Cu}, \mathrm{Fe}, \mathrm{Mn}, \mathrm{Pb}$ and $\mathrm{Zn}$ in soil, extracted by the different extractants. Note

Table 1 - Soil chemical attributes and total concentrations of heavy metals in the sampled points

\begin{tabular}{|c|c|c|c|c|c|c|c|c|}
\hline \multirow{2}{*}{ Determination } & \multirow{2}{*}{ Unit } & \multicolumn{7}{|c|}{ Soil sampled points } \\
\hline & & 1 & 2 & 3 & 4 & 5 & 6 & 7 \\
\hline $\mathrm{pH} \mathrm{CaCl}_{2}$ & & 5.8 & 5.8 & 5.2 & 5.5 & 5.5 & 5.3 & 5.2 \\
\hline O.M. & $\mathrm{g} \mathrm{kg}^{-1}$ & 29.8 & 36.3 & 34.4 & 37.2 & 35.4 & 36.3 & 33.5 \\
\hline $\mathrm{P}$ & $\mathrm{mg} \mathrm{dm} \mathrm{m}^{-3}$ & 59.1 & 36 & 56.1 & 22.1 & 21.5 & 20.8 & 17.5 \\
\hline $\mathrm{K}^{+}$ & $\mathrm{mmol}_{\mathrm{c}} \mathrm{dm}^{-3}$ & 12 & 14.1 & 5.4 & 11.8 & 11.3 & 7.4 & 8.7 \\
\hline $\mathrm{Ca}^{2+}$ & $\mathrm{mmol}_{\mathrm{c}} \mathrm{dm}^{-3}$ & 44 & 33 & 38 & 41 & 36 & 36 & 17 \\
\hline $\mathrm{Mg}^{2+}$ & $\mathrm{mmol}_{\mathrm{c}} \mathrm{dm}^{-3}$ & 8 & 19 & 20 & 24 & 20 & 16 & 5 \\
\hline $\mathrm{H}+\mathrm{Al}$ & $\mathrm{mmol}_{\mathrm{c}} \mathrm{dm}^{-3}$ & 24 & 26 & 36 & 29 & 29 & 31 & 61 \\
\hline $\mathrm{Al}^{3+}$ & $\mathrm{mmol}_{\mathrm{c}} \mathrm{dm}^{-3}$ & 0 & 0 & 0 & 0 & 0 & 0 & 0 \\
\hline SB & $\mathrm{mmol}_{\mathrm{c}} \mathrm{dm}^{-3}$ & 64 & 66.1 & 63.4 & 76.8 & 67.3 & 59.4 & 30.7 \\
\hline $\mathrm{T}$ & $\mathrm{mmol}_{\mathrm{c}} \mathrm{dm}^{-3}$ & 88 & 92 & 99 & 106 & 96 & 90 & 92 \\
\hline $\mathrm{V}$ & $\%$ & 73 & 72 & 64 & 73 & 70 & 66 & 33 \\
\hline $\mathrm{Cd}$ & $\mathrm{mg} \mathrm{kg}^{-1}$ & 25 & 23 & 20 & 23 & 26 & 28 & 27 \\
\hline $\mathrm{Cu}$ & $\mathrm{mg} \mathrm{kg}^{-1}$ & 272 & 141 & 115 & 121 & 144 & 166 & 153 \\
\hline $\mathrm{Fe}$ & $\mathrm{mg} \mathrm{kg}^{-1}$ & 537 & 936 & 861 & 510 & 99 & 100 & 97 \\
\hline $\mathrm{Mn}$ & $\mathrm{mg} \mathrm{kg}^{-1}$ & 540 & 563 & 536 & 583 & 664 & 719 & 570 \\
\hline $\mathrm{Pb}$ & $\mathrm{mg} \mathrm{kg}^{-1}$ & 333 & 208 & 174 & 198 & 226 & 244 & 229 \\
\hline $\mathrm{Zn}$ & $\mathrm{mg} \mathrm{kg}^{-1}$ & 554 & 189 & 113 & 106 & 106 & 108 & 102 \\
\hline
\end{tabular}

Rev. Ceres, Viçosa, v. 59, n.3, p. 406-413, mai/jun, 2012 
that the organic acid extractant, in general, has extracted higher concentrations of $\mathrm{Cd}, \mathrm{Cu}, \mathrm{Fe}$ and $\mathrm{Mn}$ in soil, when compared to other extractants, and for Fe and $\mathrm{Mn}$, these values were much higher than the observed in the other soils. Low molecular weight organic acids in the rhizosphere, such as those used to make the extraction solution, are effective in the solubilization of elements linked to the solid fraction of the soil (Krishnamurti et al., 1997).

For $\mathrm{Pb}$ and $\mathrm{Zn}$, in almost all soils, Mehlich-1 extracted the most. It can also be noted that in P1, which was closest to the source of pollution, and, consequently, the most contaminated point, the heavy metals were most extracted first by the extractant Mehlich-1, followed by $\mathrm{HCl}$, except for Fe and Mn. Acid extractants extract elements mainly by the dissolution of clay minerals, the amount being dependent on the acid concentration, extraction time and on the soil/solution relationship. The acid extractant Mehlich-1, according to Nascimento et al. (2002) may have negative aspects for the ability to extract forms linked to specific adsorption sites due to its acidity. Extractor $\mathrm{HCl}$ $0,01 \mathrm{~mol} \mathrm{~L}^{-1}$, which is used to extract exchangeable cations or weakly adsorbed, has demonstrated its ability to displace $\mathrm{Cd}$ and $\mathrm{Zn}$ adsorbed on Fe and Mn oxides, carbonates or decaying organic matter (Amaral Sobrinho et al., 2009). Even this behavior presenting the extracted quantities correlated with the absorbed by the plants (Paula et al., 1998) as can be seen in Figures 1, 2, 3 and 4.

It is interesting to observe the differential behavior of DTPA and Mehlich-1, used for assessing Zn availability to plants. Mehlich-1 was able to extract more than DTPA(Table

Table 2 - Concentrations of $\mathrm{Cd}, \mathrm{Cu}, \mathrm{Fe}, \mathrm{Mn}, \mathrm{Pb}$ and $\mathrm{Zn}$ in the soil, in $\mathrm{mg} \mathrm{dm}^{-3}$, extracted by Mehlich-1, DTPA, Organic acids (OA) and $\mathrm{HCl} 0.1 \mathrm{~mol} \mathrm{~L}^{-1}$ in different sampled points, before the cultivations

\begin{tabular}{|c|c|c|c|c|c|c|c|}
\hline \multirow{3}{*}{ Extractants } & \multicolumn{7}{|c|}{ Soil sampled points } \\
\hline & 1 & 2 & 3 & 4 & 5 & 6 & 7 \\
\hline & \multicolumn{7}{|c|}{$\mathrm{mg} \mathrm{dm}^{-3}$} \\
\hline \multicolumn{8}{|c|}{$\mathrm{Cd}$} \\
\hline Mehlich-1 & $0.85^{1}$ & 0.22 & 0.16 & 0.09 & 0.06 & 0.06 & 0.04 \\
\hline DTPA & 0.61 & 0.15 & 0.08 & 0.04 & 0.04 & 0.03 & 0.03 \\
\hline $\mathrm{OA}$ & 0.39 & 0.16 & 0.25 & 0.10 & 0.13 & 0.08 & 0.13 \\
\hline $\mathrm{HCl}$ & 0.76 & 0.16 & 0.09 & 0.05 & 0.02 & 0.01 & 0.01 \\
\hline \multicolumn{8}{|c|}{$\mathrm{Cu}$} \\
\hline Mehlich-1 & 101 & 19 & 11 & 9 & 12 & 15 & 13 \\
\hline DTPA & 73 & 16 & 9 & 8 & 11 & 12 & 11 \\
\hline $\mathrm{OA}$ & 87 & 33 & 23 & 18 & 22 & 26 & 21 \\
\hline $\mathrm{HCl}$ & 86 & 15 & 9 & 7 & 9 & 12 & 10 \\
\hline \multicolumn{8}{|c|}{$\mathrm{Fe}$} \\
\hline Mehlich-1 & 34 & 31 & 35 & 34 & 37 & 39 & 91 \\
\hline DTPA & 11 & 12 & 13 & 12 & 13 & 13 & 32 \\
\hline $\mathrm{OA}$ & 983 & 869 & 867 & 938 & 971 & 957 & 1043 \\
\hline $\mathrm{HCl}$ & 8 & 6 & 8 & 5 & 5 & 6 & 19 \\
\hline \multicolumn{8}{|c|}{$\mathrm{Mn}$} \\
\hline Mehlich-1 & 88 & 103 & 93 & 93 & 103 & 111 & 93 \\
\hline DTPA & 23 & 41 & 36 & 35 & 40 & 49 & 62 \\
\hline $\mathrm{OA}$ & 167 & 156 & 315 & 180 & 205 & 246 & 184 \\
\hline $\mathrm{HCl}$ & 36 & 48 & 48 & 38 & 41 & 55 & 55 \\
\hline \multicolumn{8}{|c|}{$\mathrm{Pb}$} \\
\hline Mehlich-1 & 93 & 17 & 10 & 8 & 12 & 14 & 12 \\
\hline DTPA & 64 & 15 & 9 & 8 & 10 & 11 & 11 \\
\hline $\mathrm{OA}$ & 49 & 16 & 18 & 9 & 12 & 13 & 11 \\
\hline $\mathrm{HCl}$ & 74 & 12 & 7 & 5 & 8 & 11 & 9 \\
\hline \multicolumn{8}{|c|}{$\mathrm{Zn}$} \\
\hline Mehlich-1 & 361 & 83 & 36 & 24 & 17 & 12 & 7 \\
\hline DTPA & 250 & 55 & 21 & 12 & 8 & 5 & 3 \\
\hline OA & 159 & 55 & 48 & 16 & 10 & 8 & 5 \\
\hline $\mathrm{HCl}$ & 259 & 67 & 30 & 18 & 11 & 9 & 5 \\
\hline
\end{tabular}

${ }^{1}$ Mean of four replicates 
2). The greater extraction ability of Mehlich-1 is due to its relatively high acidity, which has probably solubilized part of $\mathrm{Zn}$ adsorbed to oxides, while DTPA, since it is an alkali extractor, showed no ability to extract the zinc of the oxides. Similar results can be found in Ribeiro Filho et al. (2001) with the extraction of $\mathrm{Cd}, \mathrm{Cu}, \mathrm{Fe}, \mathrm{Mn}, \mathrm{Pb}$ and $\mathrm{Zn}$ from soil taken from area of Zn processing waste, and Korcak \& Fanning (1978), who found great extraction ability of Mehlich-1 in relation to DTPA for $\mathrm{Cd}, \mathrm{Cu}, \mathrm{Ni}$, and $\mathrm{Zn}$ in soils with excessive concentrations of these elements.

Paula et al. (1998), both in field conditions and in greenhouse conditions, using dilute acid extractants such as Mehlich-1 and $\mathrm{HCl} 0.1 \mathrm{~mol} \mathrm{~L}^{-1}$, have extracted more soil elements than with chelating agents, in this case DTPA. Possibly due to reduced $\mathrm{pH}$ of the extract at around 2.5, acidic extractants solubilize compounds that are not extracted by chelating agents.

Extractor effectiveness to assess the available concentrations at the studied points was determined by the significance of correlations. Figures 1 and 2 show the correlations for $\mathrm{Cd}, \mathrm{Cu}, \mathrm{Fe}, \mathrm{Mn}, \mathrm{Pb}$ and $\mathrm{Zn}$ among the extractants examined and the contents of rice leaves for diagnosis, and Figures 3 and 4 show the correlations among the extractants examined and the content of soybean leaves for diagnosis.

\section{Rice}

The contents extracted by DTPA, HCl and Mehlich-1 had positive correlations with the concentrations of $\mathrm{Cd}$, $\mathrm{Cu}$ and $\mathrm{Fe}$ in the plant, except for the organic acid extractant (Figure 1). For Cd and Fe correlations were significant at $1 \%$ and for $\mathrm{Cu}$ at $5 \%$. The organic acid extractant was positively correlated to Fe ( $\mathrm{p}<0.05)$.

Mn showed non-significant negative correlation for Mehlich-1 and organic acid extractants (Figure 2). Such negative correlations obtained with the Mn may be due to chelating capabilities (O’Connor, 1988), or to the exhaustion of the extracting ability of the chemical solution due to the high concentration of soluble ions in different elements, limiting the extraction of this element from the soil. Positive correlation was shown to DTPA and $\mathrm{HCl}$ extractants, and was significant only for DTPA.

For Zn, in all extractants examined correlations were significant at $1 \%$ concentration in the plant. A similar result was found in the literature for an experiment with flue dust in corn and lettuce carried out by Accioly (1996). Cunha et al. (2008) have found highly significant correlations ( $p<0.01$ ) between the concentrations of $\mathrm{Cd}$ and $\mathrm{Zn}$ in plants and those obtained by different extractants, including DTPA and Mehlich-1. Results indicate that chemical methods have similar effectiveness when assessing the availability, in the case of Cd and Zn, for plants in contaminated soil.
The analysis of the concentrations of $\mathrm{Pb}$ showed correlation with the DTPA extractant alone. Andrade et al. (2010) find significant and high correlations of the amounts extracted with DTPA with the accumulated amounts of $\mathrm{Pb}$ in rice plants and the concentrations in roots and shoots.

When assessing the effects of flue dust application to the soil, researchers found that Mehlich-1 and DTPA were not efficient at extracting $\mathrm{Pb}$ and $\mathrm{Cd}$, only $\mathrm{Zn}$ (Accioly, 1996). In another study, using the same extractants, Santos et al. (2002) found that none of them was effective in assessing the availability of $\mathrm{Pb}, \mathrm{Cd}, \mathrm{Cr}$ and $\mathrm{Ni}$ for corn plant. The authors have described that the lack of
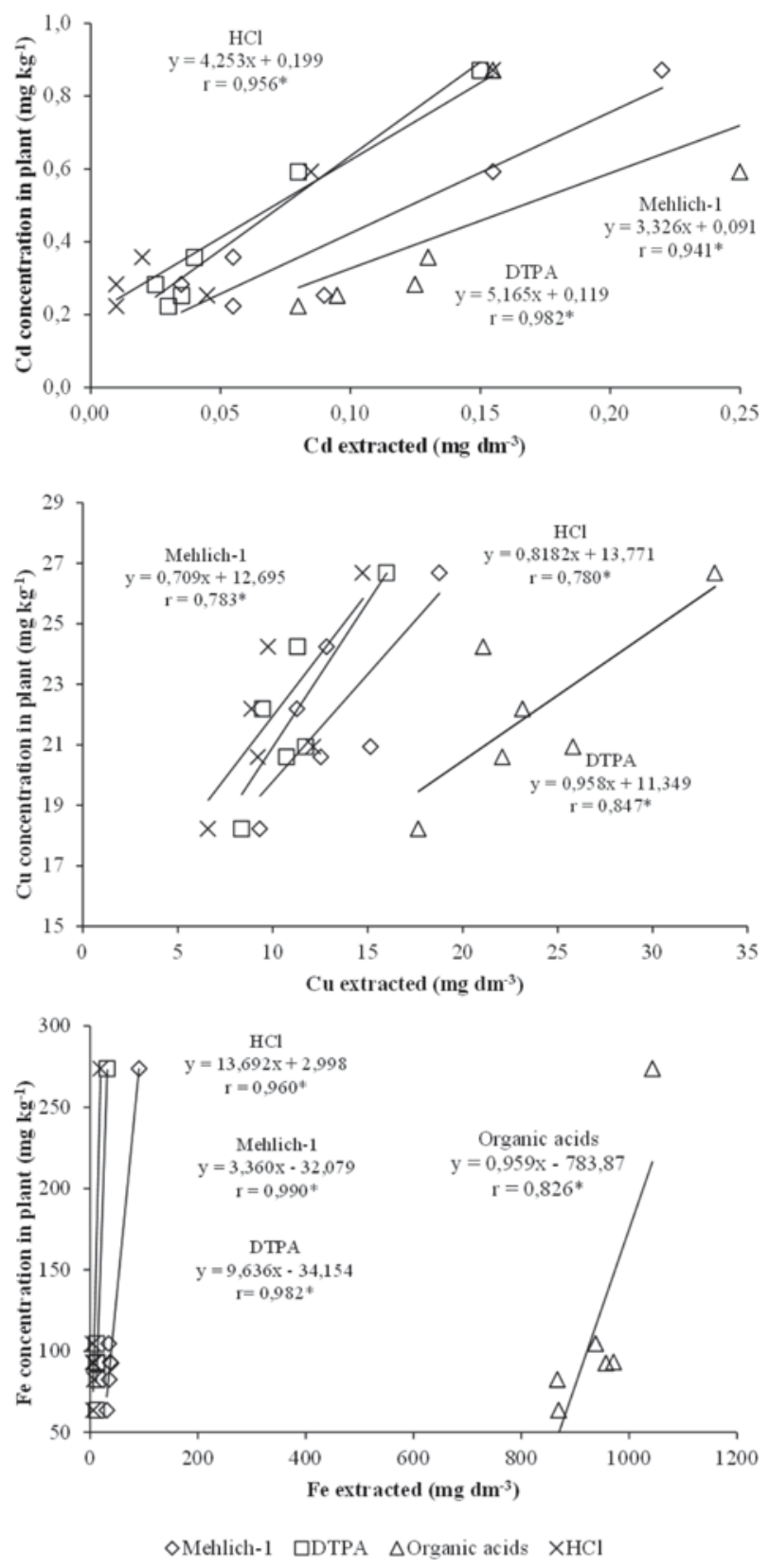

Figure 1 - Linear correlations of concentration of $\mathrm{Cd}, \mathrm{Cu}$ and $\mathrm{Fe}$ in the leaf used for diagnostic in rice and concentrations extracted from the soil by Mehlich-1, DTPA, organic acids, and $\mathrm{HCl}$ (*significant at 5\%). 
correlation of $\mathrm{Cd}$, Cr and Ni may be due, among other factors, to low concentrations in the soil samples studied, while for $\mathrm{Pb}$ the lack of significant correlation can be due to the small variation of element concentrations in soil and plant. When compared to the results of this study, we may note that very high levels in the soil can also affect the extraction efficiency of chemical extractants, thereby influencing the correlation with foliar concentrations.

Unlike the results found by Accioly (1996) and Santos et al. (2002) levels of $\mathrm{Cd}$ and $\mathrm{Pb}$ found in this study showed positive correlation with DTPA, in agreement with Andrade et al. (2010). High and significant correlations among
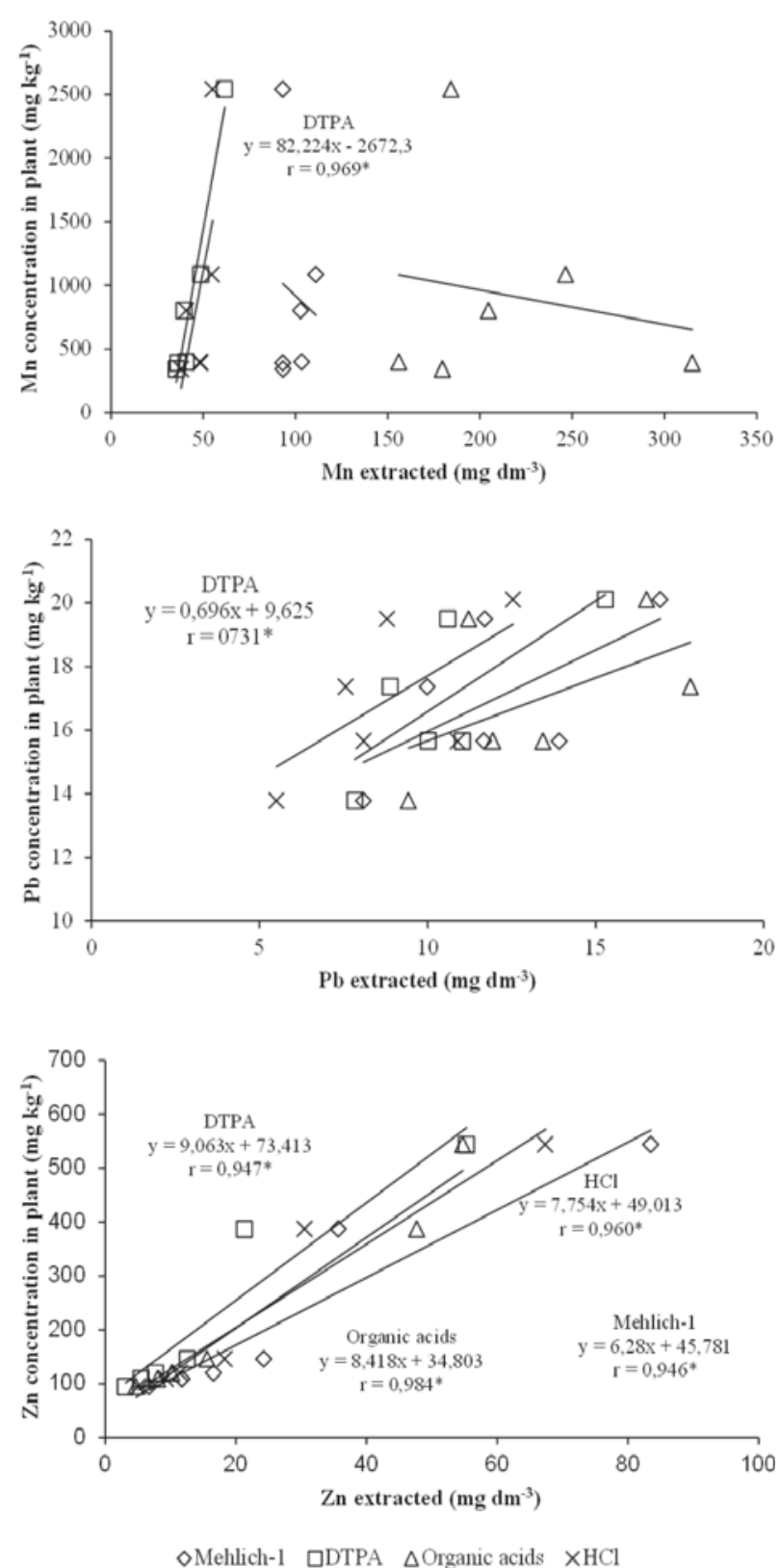

Figure 2 - Linear correlations of concentration of $\mathrm{Mn}, \mathrm{Pb}$ and $\mathrm{Zn}$ in the leaf used for diagnostic in rice and concentrations extracted from the soil by Mehlich-1, DTPA, organic acids, and $\mathrm{HCl}\left(*^{*}\right.$ significant at 5\%). concentrations of zinc, cadmium and lead extracted with DTPA, and concentrations of these elements in plants, have been found in several studies (Qian et al., 1996; Paula et al., 1998; Amaral Sobrinho et al., 2009).

For the organic acid extractant, although it has extracted greater amounts of $\mathrm{Cd}, \mathrm{Cu}, \mathrm{Fe}$ and $\mathrm{Mn}$ in all soils, there was not correlation between the concentrations of such elements in the soil and in leaves used for diagnosis. However, a significant correlation between concentration extracted from soil and present in the leaves was found for Zn. Researchers found a significant correlation between content in soil and leaf using this
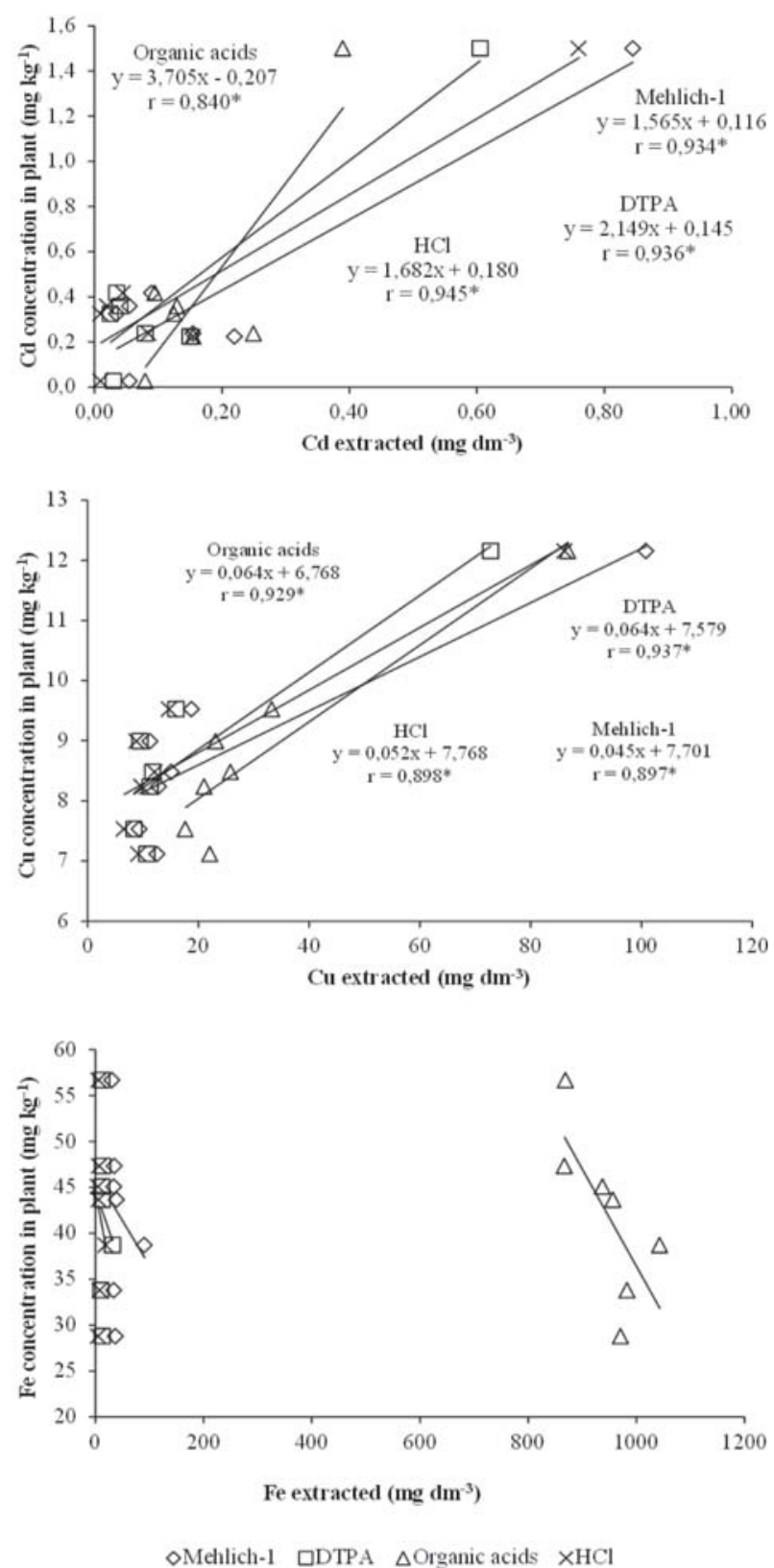

Figure 3 - Linear correlations of concentration of $\mathrm{Cd}, \mathrm{Cu}$ and $\mathrm{Fe}$ in the leaf used for diagnostic in soybean and concentrations extracted from the soil by Mehlich-1, DTPA, organic acids, and $\mathrm{HCl}\left({ }^{*}\right.$ - significant at 5\%).

Rev. Ceres, Viçosa, v. 59, n.3, p. 406-413, mai/jun, 2012 
method to assess $\mathrm{Cu}, \mathrm{Ni}, \mathrm{Pb}$ and $\mathrm{Zn}$ in leaves of banana, peach and coffee (Pires et al., 2004). However, it may be noted that the heavy metals evaluated by Pires et al. (2004) were added through sewage sludge, rich in organic material, with $300 \mathrm{~g} \mathrm{~kg}^{-1}$ organic carbon on average. This probably explains why organic acid extractant was not effective, since the organic matter content of soils in the study was around $35 \mathrm{~g} \mathrm{~kg}^{-1}$. This extactor probably has ability to extract elements linked to the organic fraction and not those associated with the mineral fraction. Another possibility is that the organic acids used in this solution were not effective to solubilize the heavy metals
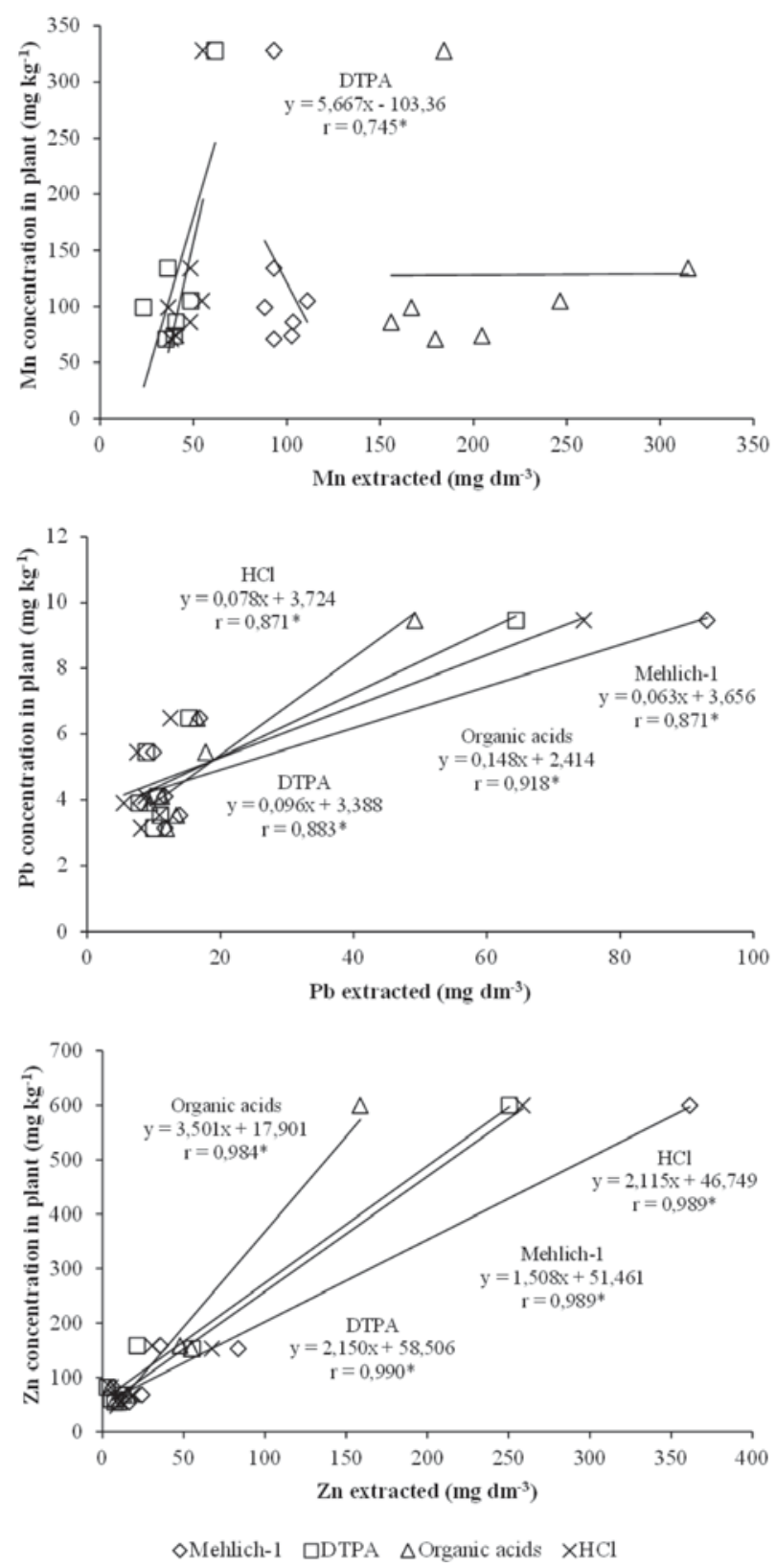

Figure 4 - Linear correlations of concentration of $\mathrm{Mn}, \mathrm{Pb}$ and $\mathrm{Zn}$ in the leaf used for diagnostic in soybean and concentrations extracted from the soil by Mehlich-1, DTPA, organic acids, and $\mathrm{HCl}(*$ - significant at 5\%). available for rice. To determine the types of organic acids and their concentrations, and thus draw up the extractor, Pires (2004) used crops like sugar cane, signalgrass and corn which belong to the family Poaceae just as rice.

\section{Soybean}

Figures 3 and 4 show the correlations in soil concentrations of $\mathrm{Cd}, \mathrm{Cu}, \mathrm{Fe}, \mathrm{Mn}, \mathrm{Pb}$ and $\mathrm{Zn}$ obtained with the extractants examined and the contents in the leaves used for diagnosis of soybean. For $\mathrm{Cd}, \mathrm{Cu}, \mathrm{Fe}$, $\mathrm{Mn}, \mathrm{Pb}$ and $\mathrm{Zn}$, all extractants resulted in positive correlation between soil concentrations and the contents of leaves.

Similar results were found by Silva (1999) and Ribeiro Filho et al. (2001) when working with DTPA and Mehlich1 solutions, where both proved to be appropriate to assess the availability of $\mathrm{Cd}, \mathrm{Ni}, \mathrm{Zn}$ and $\mathrm{Pb}$, as well as for $\mathrm{Pb}$ extracted with DTPA and Mehlich-3.

For Mn only DTPA had significant correlation ( $p<0.05)$, whereas for Fe no extractor was effective. One possible explanation for Fe could be its competition with Cd for absorption sites on the plasma membrane (Siedlecka \& Krupa, 1999), as well as due to the similarity between the ionic radius of Fe and $\mathrm{Zn}$ (Woolhouse, 1983); the excess of $\mathrm{Zn}$ could inhibit the absorption of Fe, leading to plant deficiency, even though there is Fe in the soil solution.

The organic acid extractant, unlike what has occurred with rice, had a positive correlation with the concentrations of $\mathrm{Cd}, \mathrm{Cu}, \mathrm{Pb}$ and $\mathrm{Zn}$ in the leaves used for diagnosis, in agreement with previously published results (Pires et al., 2004). Such results remove the assumption that this extractant would be effective only for soils with high organic matter content, since we have used the same soil for both crops. But it emphasizes the possibility that this mixture of organic acids might not be able to be used for any crop, which would require more studies on the subject.

\section{CONCLUSION}

The extractants Mehlich-1, $\mathrm{HCl} 0.1 \mathrm{~mol} \mathrm{~L}^{-1}$ and DTPA were effective to assess the available concentrations of $\mathrm{Cd}, \mathrm{Cu}, \mathrm{Fe}, \mathrm{Pb}$ and $\mathrm{Zn}$ in contaminated soils for rice culture.

The extractants Mehlich-1, HCl $0.1 \mathrm{~mol} \mathrm{~L}^{-1}$, DTPA and organic acid were effective in assessing the availability of $\mathrm{Cd}, \mathrm{Cu}, \mathrm{Pb}$ and $\mathrm{Zn}$ in soils with high concentrations of these elements, when soybean was used as extractor plant.

Only DTPA was efficient in assessing the availability of Mn for plants.

The extractants Mehlich-1, HCl $0.1 \mathrm{~mol} \mathrm{~L}^{-1}$, DTPA and organic acid were not effective in assessing the availability of Fe, in soils with high concentrations of this element. 


\section{REFERENCES}

Abreu CA, Abreu MF \& Berton RS (2002) Análise química de solos para metais pesados. In: Alvarez V. VH, Schaefer CEGR, Barros NF, Mello JWV \& Costa LM (Ed.) Tópicos em Ciência do Solo, v.2, Viçosa, SBCS, p.645-692.

Abreu CA, Abreu MF, Raij B. van \& Santos WR (1995) Comparação de métodos de analise para avaliar a disponibilidade de metais pesados em solos. Revista Brasileira de Ciência do Solo, 19:463-468.

Abreu CA; Abreu MF \& Andrade JC (1998) Distribuição de Chumbo no perfil do solo avaliado pelas soluções de DTPA e Mehlich3. Bragantia, 57:185-192.

Accioly AMA (1996) Pó de forno de siderurgia como fonte de micronutrientes e seu efeito no solo e na planta. Dissertação de mestrado. Universidade Federal de Lavras, Lavras, 70p.

Amaral Sobrinho, N M B A; Barra, C M \& Lã, O R (2009) Química dos metais pesados no solo. In: Melo, V.F. \& Alleoni, L R F. (Eds). Química e Mineralogia do solo: Aplicações. Viçosa, SBCS, p. 249-312.

Andrade AFM, Sobrinho NMBA \& Mazu N (2010) Teor de zinco, cádmio e chumbo em plantas de arroz em solos incubados com resíduo siderúrgico. Revista Brasileira de Engenharia Agrícola e Ambiental, 14:1087-1093.

Companhia de tecnologia e saneamento ambiental - CETESB (2005) Decisão de diretoria No . 195-2005- E, Nov. de 2005: Valores orientadores para solos e águas subterrâneas no estado de São Paulo. Disponível em: <http://www.cetesb.sp.gov.br> Acessado em: 30 de novembro de 2011

Cunha KPV, Nascimento CWA, Pimentel RMM, Accioly AMA \& Silva AJ (2008) Disponibilidade, acúmulo e toxidez de cádmio e zinco em milho cultivado em solo contaminado. Revista Brasileira Ciência do Solo, 32:1319-1328.

Embrapa (1999) Centro Nacional de Pesquisa de Solos. Sistema Brasileiro de Classificação de Solo. Brasília, Embrapa Produção de Informação, 412p.

Korcak RF \& Fanning DS (1978) Extractability of cadmium, copper, nickel, and zinc by double acid versus DTPA and plant content at excessive soil levels. Journal of Environmental Quality, 7:506-512.

Krishnamurti GSR, Cielinky G, Huang PM \& Rees KCJ van (1997) Kinetics of cadmium release from soils as influenced by organic acids: implication in cadmium availability. Journal of Environmental Quality, 26:271-277.

Lindsay WL \& Norvell WA (1978) Development of a DTPA soil test for zinc, iron, manganese and copper. Soil Science Society of America Journal, 42:421-428.

Malavolta E, Vitti GC \& Oliveira SA (1997) Avaliação do estado nutricional das plantas: princípios e aplicações. 2 ed. Piracicaba, POTAFOS, 319p.

Mattiazzo ME, Berton RS \& Cruz MCP (2001) Disponibilidade avaliação de metais pesados potencialmente tóxicos. In: Ferreira ME (Ed.). Micronutrientes e elementos tóxicos na agricultura. Jaboticabal, CNPq; FAPESP; POTAFOS, p. 213-234

Mench M J \& Martin E (1991)Mobilization of cadmium and other metals from two soils by root exudates of Zea mays L., Nicotiana tabacum L. and Nicotiana rustica L. Plant and Soil, 132:187-196

Miyazawa, M; Pavan, M A.; Muraoka, T; Carmo, C A F S \& Melo, W J (2009) Análise química de tecido vegetal. In: Silva FC (Ed.). Manual de análises químicas de solos, plantas e fertilizantes. Brasília, EMBRAPA, p.192-233.
Nascimento, C W A; Fontes, R L F; Neves, J C L \& Melício, A C F C (2002) Fracionamento, dessorção e extração química de zinco em Latossolos. Revista Brasileira de Ciência do Solo, 26:599-606.

Nieuwenhuize J, Poley-Vos CH, Akker AH van den \& Delft W van (1991) Comparison of microwave and conventional extraction techniques for the determinations of metals in soil, sediment and sludge sample by atomic spectrometry. The Analyst, 116:347-351.

O’Connor GA (1988) Use and misuse of the DTPA soil test. Journal of Environmental Quality, 17:715-718.

Oliva SR, Raitio H \& Mingorance MD (2003) Comparison of two wet digestion procedures for multi-element analysis of plant samples. Communications in Soil Science and Plant Analysis, 34:2913-2923.

Paula MB, Carvalho JG, Nogueira FD \& Mesquita HA (1998) Curva de resposta e avaliação de extratores para zinco disponível em solos hidromórficos e aluviais sob arroz inundado. Revista Brasileira de Ciência do Solo, 15:49-55.

Pimentel Gomes, F \& Garcia, CH (2002) Estatística aplicada a experimentos agronômicos e florestais. Piracicaba, FEALQ. 309p.

Pires AMM, Mattiazzo ME \& Berton RS (2004) Ácidos orgânicos como extratores de metais pesados fitodisponíveis em solos tratados com lodo de esgoto. Pesquisa Agropecuária Brasileira, 39:671-676.

Qian J, Shan X, Wang Z \& Tu Q (1996) Distribution and plant availability of heavy metals in different particle size fractions of soil, The Science of the Total Environment, 186:131-141.

Raij B van (1994) New diagnostic techniques, universal soil extractants. Communications in Soil Science and Plant Analysis, 25:799-816.

Raij B van, Andrade JC, Cantarella H \& Quaggio JA (Ed) (2001) Analise química para avaliação da fertilidade de solos tropicais. Campinas: Instituto Agronômico, 285p.

Raij B van, Cantarella H, Quaggio JA \& Furlani AMC (1997) Recomendações de adubação e calagem para o Estado de São Paulo. 2.ed., Campinas, Instituto Agronômico, 285p. (Boletim Técnico, 100)

Ribeiro Filho MR, Siqueira JO, Cury N \& Simão JBP (2001) Fracionamento e biodisponibilidade de metais em solo contaminado incubado com materiais orgânicos e inorgânicos. Revista Brasileira de Ciência do Solo, 25:495-507.

Santos GCG, Abreu CA, Camargo AO \& Abreu MF (2002) Pó-deaciaria como fonte de zinco para milho e seu efeito na disponibilidade de metais pesados. Bragantia, 61:257-266.

Siedlecka A \& Krupa Z (1999) Cd/Fe interactions in higher plants - Its consequences for the photosynthetic apparatus. Photosynthetica, 36:321-331.

Silva FAM (1999) Fracionamento e biodisponibilidade de metais para o feijoeiro (Phaseolus vulgaris L.) em solos tratados com pó de forno de aciaria elétrica. Dissertação de Mestrado, Universidade Federal de Lavras. Lavras, 80p.

Silva FC (2009) Manual de análises químicas de solos, plantas e fertilizantes. Brasília, EMBRAPA. 627p.

Wear JI \& Sommer AL (1947) Acid-extractable zinc of soils in relation to the occurrence of zinc deficiency symptoms of corns: a method of analysis. Soil Science Society of America Proceedings, 12:143-144.

Woolhouse HW (1983) Toxicity and tolerance in the responses of plant to metals. In: Lange OL, Osmond CB \& Ziegler H (Ed). (1983) Encyclopedia of plant physiology. Berlin, Springer, p.245-300. 